\title{
CYTOKINE EXPRESSION IN B-CELL NON-HODGKIN LYMPHOMAS
}

\author{
H. MERZ* ${ }^{*}$ A. FLIEDNER $\dagger$, TH. LEHRNBECHER *, W. SEBALD*, H. K. MÜLLER-HERMELINK † AND \\ A. C. FELLER $†$ \\ -Department for Physiological Chemistry, Koellikerstr. 2, 8700 Würzburg F.R.G. †Department of Pathology, \\ University of Würzburg, Josef-Schneider-Str. 2, 8700 Würzburg F.R.G.
}

\section{SUMMARY}

Cytokine expression of potentially active B-cell growth factors (IL-2, IL-4, IL-6) was investigated by means of mRNA-expression in 29 cases of malignant non-Hodgkin B-cell lymphomas. Strong signals were found for IL-4 and IL-6 in two and five cases, respectively, whereas the majority of the remaining cases did not show any detectable mRNA-signals for these growth factors. Comparing these results with those of the immunohistochemistry, it could be demonstrated that at least in some of these cases the signal was due to an autocrine or paracrine phenomenon of the tumour cells.

KEY WORDS Cytokines Malignant lymphoma In situ hybridization

\section{INTRODUCTION}

Normal proliferation, differentiation and activation of hematopoietic and lymphoid cell compartments are regulated by a complex network of interacting cytokines frequently produced by helper/ inducer T-cells. Most of these extremely potent factors have been shown to have stimulatory effects, while others can act as downregulatory agents. Intriguing new data indicate that a cytokine secreted by tumour infiltrating cells or by the tumour cells themselves as an autocrine or paracrine phenomenon may have antitumoural as well as growth factor activity (Biondi et al., 1989; Tepper et al., 1989; Kupper et al., 1987).

The clinical course of malignant lymphomas shows a broad range of behaviour with respect to tumour growth and therapy response. Differences can be found not only between high and lowgrade malignant lymphomas but even within the same entity with identical phenotypic properties. This variation in behaviour raises the question as to the influence of cytokines, which may be produced by infiltrating cells in a malignant lymphoma or by the lymphoma cells themselves.

Since some cytokines are known to exert a strong influence on B-cell proliferation and differentiation (Wörmann et al., 1987; Balkwill and Burke, 1989) we investigated a number of small lymphocyticand large cell (low and high grade) malignant B-cell lymphomas to determine their basic capacity for cytokine production and possible differences between the various lymphoma entities.

\section{MATERIAL AND METHODS}

Primary biopsies from 29 untreated patients with malignant lymphomas of nodal origin were investigated. A portion of the lymph node was fixed in 4 per cent formaldehyde and a portion snap

Addressee for correspondence: A. C. Feller, Department of Pathology, University of Würzburg, Josef-Schneider-Str. 2, 8700 Würzburg F.R.G. 
frozen in liquid nitrogen within $1 \mathrm{~h}$ after biopsy. The formalin-fixed material was embedded in paraffin and $5 \mu \mathrm{m}$ paraffin sections were cut and stained for $\mathrm{H}$ and $\mathrm{E}$, Giemsa and PAS. Cryostat sections were prepared from the frozen material and immunostained with monoclonal antibodics for $\mathrm{CD} 2, \mathrm{CD} 3, \mathrm{CD} 5, \mathrm{CD} 19, \mathrm{CD} 22, \mathrm{CD} 23, \mathrm{CD} 25, \mathrm{Ki}-\mathrm{M} 4$ (dendritic reticulum cells) using an immunoperoxidase method.

\section{RNA preparation and Northern blotting}

Frozen tumour material was disrupted with an Ultraturrax tissuehomogenizer and suspended in a guanidine thiocyanate buffer (Chirgwin et al., 1979) followed by caesium-chloride gradient centrifugation (Glisin et al., 1974). Twenty $\mu \mathrm{g}$ of total RNA per lane was size-fractionated by electrophoresis in 6 per cent formaldehyde/1.5 per cent agarose gels (Lehrach et al., 1977). Before RNA-transfer to nylon membranes (Hybond, Amersham), the gels were stained with ethidium bromide to verify equal quantities of RNA (Thomas, 1980). Equal amounts of total RNA of stimulated PBL (PMA $10 \mathrm{ng} / \mathrm{ml} \mathrm{Ca-ionophore-A23187} 100 \mathrm{ng} / \mathrm{ml}$ ) were used as controls.

\section{Hybridization}

Prehybridization was performed in 50 per cent formamide, $2 \times$ SSC, 0.1 per cent SDS, $20 \mathrm{~mm}$ vanadyl-ribonucleoside-complex, $200 \mu \mathrm{g} / \mathrm{ml}$ salmon sperm DNA, $200 \mu \mathrm{g} / \mathrm{ml}$ yeast-tRNA, $5 \times$ Denhardts solution, 10 per cent dextran sulfate for 4 to $6 \mathrm{~h}$ at $58^{\circ} \mathrm{C}$. Five $\mathrm{ng} / \mathrm{ml}$ of $\left[{ }^{32}\right] \mathrm{P}$-labelled anti-sense-cRNA probe was added and hybridization was performed for 12 to $16 \mathrm{~h}$. Filters were washed $2 \times 5 \mathrm{~min} 2 \times \mathrm{SSC}, 0.1$ per cent SDS at room temperature, $2 \times 30 \mathrm{~min} 2 \times \mathrm{SSC}, 0.1$ per cent SDS at $65^{\circ} \mathrm{C}, 2 \times 10 \mathrm{~min} 0 \cdot 2$ per cent SSC, 0.1 per cent $\operatorname{SDS}$ at $65^{\circ} \mathrm{C}$ to $70^{\circ} \mathrm{C}$. Filters were exposed to Kodak-X-omat film (Kodak, Rochester, U.S.A.) for 8 to $72 \mathrm{~h}$.

After exposure, RNA-blots were stripped of $\left.{ }^{32}\right]$ P-labelled probes by incubation in boiling solution of $0 \cdot 1$ per cent SDS and subsequent cooling to room temperature. Blots were reused 4 to 5 times.

\section{In situ hybridization}

Five $\mu \mathrm{m}$ cryostate sections were placed on 2 per cent 3-(Triethoxysilyl)-propylamine (Merck) activated slides and fixed in 4 per cent paraformaldehyde (Merck), 0.1 per cent glutaraldehyde (Merck) in PBS.(pH 7.5) for 60 min at room temperature and stored in 70 per cent ethanol.

Rehydrated slides were acetylated in 0.1 per cent triethanolamine ( $\mathrm{pH} 8.0$ ) (Sigma), 0.25 per cent acetic anhydride (Sigma) for $10 \mathrm{~min}$ and postfixed in 4 per cent paraformaldehyde for $10 \mathrm{~min}$, dehydrated in a series of graded ethanol and finally air-dried.

Hybridization was performed in a solution containing $4 \times \operatorname{SSC}(1 \times \mathrm{SSC}=0.15 \mathrm{M} \mathrm{NaCl}, 0.015 \mathrm{M}$ trisodium citrate), 10 per cent dextran sulfate (Sigma), vanadyl-ribonucleoside-complex $20 \mathrm{~mm}$, yeast-tRNA $200 \mu \mathrm{g} / \mathrm{ml}$ (Boehringer), salmon-sperm-DNA $200 \mu \mathrm{g} / \mathrm{ml}$ (Boehringer), BSA $500 \mu / \mathrm{ml}$ (Sigma), 50 per cent deionized formamide (BRL), Tris-HCL (pH 8.0), $10 \mathrm{~mm}$, EDTA $1 \mathrm{~mm}$. Five $\mathrm{ng}$ [ $\left.^{35}\right] \mathrm{S}$ (Amersham) labelled anti-sense or sense riboprobe were added to $20 \mu$ hybridization solution. Incubation time was 4 to $16 \mathrm{~h}$ in a humidified chamber at $50^{\circ} \mathrm{C}$. Washing was performed in $4 \times \mathrm{SSC}$ at room temperature for $10 \mathrm{~min}, 2 \times \mathrm{SSC}$ at $52^{\circ} \mathrm{C}$ for $30 \mathrm{~min}, 2 \times \mathrm{SSC}, 20 \mu \mathrm{g} / \mathrm{ml} \mathrm{RNase} \mathrm{A}$ (Boehringer) at $37^{\circ} \mathrm{C}$ for $30 \mathrm{~min}, 0.2 \times \mathrm{SSC}, 10 \mathrm{mM}$ DTT (Sigma) at $52^{\circ} \mathrm{C}$ for $30 \mathrm{~min}$. Slides were then rinsed twice in 70 per cent ethanol, $200 \mathrm{~mm}$ ammonium acetate $(\mathrm{pH} \mathrm{5.4)}$ for $10 \mathrm{~min}$, dehydrated and air-dried.

Slides were subsequently dipped in Ilford $\mathrm{K} 2$ emulsion, stored for 3 days at $4^{\circ} \mathrm{C}$, developed in Kodak D19 developer, and Giemsa stained. 


\section{Probes}

The $\mathrm{CDNA}$ of the coding region of IL-2 was cloned by $\mathrm{W}$. Sebald and the sequence was identical to the published sequence of Taniguchi et al. (1983). The cDNA of the coding region of IL-4 was originally obtained from British Biotechnology and based on the published sequence of Yokota $e t$ al. (1986). The cDNA of IL-6 was cloned by one of us (W.S.) and is identical to the published sequence of Hirano et al. (1986). The CDNA of TAC, the p55 subunit of the IL-2 receptor, was cloned and sequenced by W.S. and is in accordance with the sequence published by Leonard $e t a l$. (1984).

The expected sizes of the mRNAs for IL-2, IL-4 and IL-6 are 800-900b, 700-800b, 1300b respectively and the transcript lengths for TAC are normally found to be $1500 \mathrm{~b}$ and $3500 \mathrm{~b}$. The cDNAs of the coding regions of IL-2, IL-4, IL-6 and TAC were subcloned into transcription vectors (PSPT 18/19, Boehringer, F.R.G.).

The $\left.{ }^{32} \mathrm{P}\right]-$ or $\left[{ }^{35} \mathrm{~S}\right]$-labelled sense and anti-sense-cRNA probes were generated in in vitro transcription experiments with T7 RNA-polymerase to a specific activity of 1 to $5 \times 10^{8} \mathrm{cpm} / \mu \mathrm{g}$ cRNA (Zinn et al., 1983).

\section{RESULTS}

All 29 cases were classified as B-cell lymphomas by morphology and immunohistochemistry. Twenty cases were classified as low-grade and 9 cases as high-grade malignant lymphomas.

The exact diagnosis according to the Kiel classification (Stansfield et al., 1988) and the Working Formulation (non-Hodgkin's Lymphoma Pathologic Classification Project, 1982) as well as the immunophenotypes and the results of cytokine mRNA expression (IL-2, IL2-R, IL-4, IL-6) are detailed in Table 1. Cytokine mRNA of the lymphomas was quantified by comparison to stimulated PBL $(12 \mathrm{~h} / 36 \mathrm{~h})$ signals. The maximum signal of PBL was quantified as ++ , lower signals in the lymphomas were designated as + .

IL-2 mRNA was found at low levels in only two cases of centroblastic-centrocytic lymphoma (follicular mixed, small cleaved and large cell). IL2-R mRNA patterns were found in 16 cases, with a strong signal in one case of hairy cell leukemia (HCL). Three cases expressed the TAC antigen in the tumour cells, whereas in the remaining cases expression was confined to the infiltrating 'host' $T$ cells and macrophages as demonstrated by immunohistochemistry (CD25). In the one case of HCL exhibiting a strong mRNA signal the tumour cells showed complete positivity for CD25, whereas in the other two cases only partial positivity was found. An IL-4 signal was evident in only three cases, two of which had high levels (BCLL-small lymphocytic; $\mathrm{cb}$-diffuse large cell), indicating that in these cases it was the tumour cells themselves that exhibited this autocrine expression. Immunohistochemistry revealed a T-cell content of less than 3 per cent in both cases. The other two cases were $\mathrm{cb} / \mathrm{cc}$ (follicular mixed, small cleaved and large cell) lymphomas with a high content of $T$ cells. The remaining cases $(n=25)$ were completely negative for expression of IL-4 mRNA. Five cases ( $2 \mathrm{cb}$-diffuse large cell; $3 \mathrm{cb} / \mathrm{cc}$-follicular mixed, small cleaved and large cell) had high amounts of IL-6 transcripts (Figure 1), while all other cases were negative except for weak signals in one case of centrocytic lymphoma (diffuse, small cleaved cell) and one case of B-immunoblastic lymphoma.

Four cases with clear mRNA expression in Northern blots (case no. 11, 15, 21, 24) were additionally investigated by in situ hybridization (Figure 2a,b). All four cases showed positive signals for IL-6 mRNA in 20-60 per cent of the whole cellular infiltrate. In immunohistochemistry cases no. 21 and 24 were shown to have a non-neoplastic T-cell content of less than 10 per cent (Table 1). 
Table 1. Detailed data of immunophenotypic properties and mRNA expression in human B-cell lymphomas

\begin{tabular}{|c|c|c|c|c|c|c|c|}
\hline \multirow[b]{2}{*}{ No. } & \multicolumn{3}{|c|}{ Immunophenotype* } & \multicolumn{4}{|c|}{ mRNA expression $\dagger$} \\
\hline & Diagnosis & CD3 $(\%)$ & CD25 & IL2 & IL2-R & IL4 & IL6 \\
\hline 1 & BCLL & 5 & s & - & - & ++ & - \\
\hline 2 & BCLL & 10 & $\mathbf{s}$ & - & $(+)$ & - & - \\
\hline 3 & IC & 5 & s & - & $(+)$ & - & - \\
\hline 4 & IC & 10 & - & - & $(+)$ & - & - \\
\hline 5 & BCLL/IC & 10 & $\mathbf{s}$ & - & $(+)$ & - & - \\
\hline 6 & $\mathrm{HCL}$ & 25 & ++ & - & ++ & - & - \\
\hline 7 & $\mathrm{HCL}$ & 25 & + & - & + & - & - \\
\hline 8 & $\mathrm{cbcc}$ & 30 & - & - & - & - & - \\
\hline 9 & $\mathrm{cb} c c$ & 20 & - & - & - & - & - \\
\hline 10 & $c b \propto c$ & 20 & $\mathbf{s}$ & $(+)$ & - & - & - \\
\hline 11 & $\mathrm{cbcc}$ & 15 & + & $(+)$ & + & - & ++ \\
\hline 12 & $\mathrm{cb} \propto \mathrm{c}$ & 40 & $s$ & - & - & - & - \\
\hline 13 & $c b c c$ & 30 & + & - & + & - & ++ \\
\hline 14 & $c b \propto c$ & 15 & + & - & + & + & - \\
\hline 15 & $c b c c$ & 20 & s & - & - & - & - \\
\hline 16 & $\mathrm{cbcc}$ & 25 & s & - & $(+)$ & - & $+t$ \\
\hline 17 & $c c$ & 20 & - & - & - & - & - \\
\hline 18 & $\mathrm{cc}$ & 5 & - & - & $(+)$ & - & $(+)$ \\
\hline 19 & $c c$ & 10 & $\mathbf{s}$ & - & + & - & - \\
\hline 20 & cc & 5 & n.t. & - & - & - & - \\
\hline 21 & $\mathrm{cb}$ & 10 & $\mathrm{~m}++$ & - & + & - & ++ \\
\hline 22 & $\mathrm{cb}$ & 5 & s. & - & - & ++ & - \\
\hline 23 & $\mathrm{cb}$ & 40 & - & - & - & - & - \\
\hline 24 & $\mathrm{cb}$ & 5 & $\mathrm{~m}+$ & - & $(+)$ & - & ++ \\
\hline 25 & $\mathrm{cb}$ & 10 & $\mathrm{~m}+$ & - & $(+)$ & - & - \\
\hline 26 & $\mathrm{cb}$ & 15 & $\mathbf{m}+$ & - & + & - & - \\
\hline 27 & $\mathrm{Bib}$ & 5 & $m+$ & - & - & - & - \\
\hline 28 & B ib & 5 & - & - & - & - & $(+)$ \\
\hline 29 & B ib & 10 & - & - & - & - & - \\
\hline
\end{tabular}

-Immunophenotype: s: single cells ( 3 per cent); + : 3-10 per cent positive cells; ++ : tumour cells positive; $m$ : macrophages; $n$.t.: not tested.

tmRNA expression: - : no expression detectable; $(+)$ : just detectable; + : just above intensity of controls; $++:$ within or higher intensity compared to controls.

BCLL - chronic lymphocytic leukemia of B-type; IC-immunocytoma; HCL-hairy cell leukemia; $\mathrm{cb} c c-$ centroblastic-centrocytic lymphoma; $c$-centrocytic lymphoma; $\mathrm{cb}-$ centroblastic lymphoma; B ib-B-immunoblastic lymphoma.

\section{DISCUSSION}

The factors influencing the proliferation and differentiation of malignant cells are poorly understood. Soluble growth factors acting in normal tymphoid cell development have been suggested as possible candidates (Touw et al., 1985; Wörmann et al., 1987) since malignant lymphatic cells are believed to originate from their normal counterparts arrested at defined stages of differentiation. Growth factors might stimulate the proliferation of malignant cells without inducing differentiation, thus leading to a self-sustaining growth (Greaves, 1986).

Mediating a diverse range of biomodulatory activities on B-cells IL-2, IL-4 and IL-6 represent candidate growth factors which may play an important role in the regulation of the proliferative activity of malignant B-cell lymphomas (Balkwill and Burke, 1989; Abbas, 1988). 

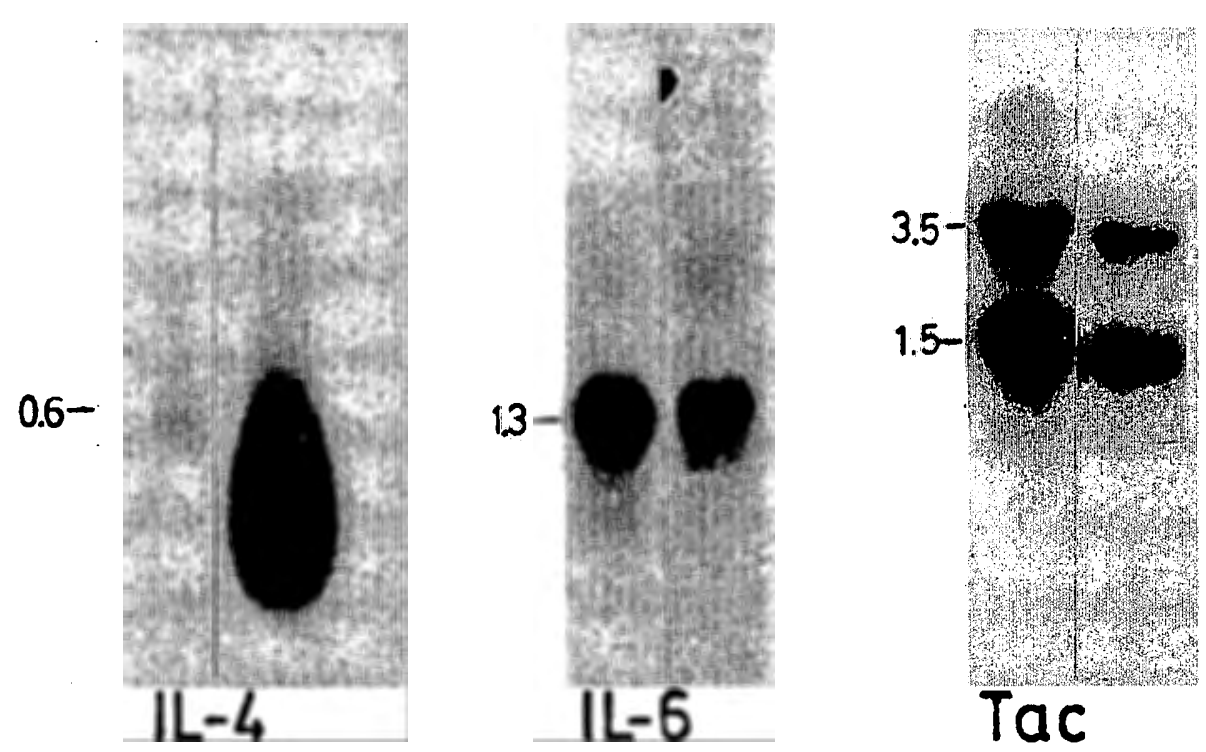

Figure 1. Northern blot analysis of stimulated peripheral T cells (lane 1) and B-cell lymphomas (lane 2). (a) IL4-lane 1: 12 h stimulation, lane 2: BCLL (case 1). (b) IL-6-lane 1: $36 \mathrm{~h}$ stimulation, lane 2: cb (case 21). (c) Tac-lane 1: $12 \mathrm{~h}$ stimulation, lane 2: HCL (case 6).

In some lymphoma cell lines a dependency, an enhanced, or even an independent growth on exogenous added growth factors such as IL-2, IL-4, IL-6 and GMCSF or a combination of these has been demonstrated (Tweeddale et al., 1989; Uchiyama et al., 1988; Yee et al., 1989; Freeman et al., 1989).

However, it must be born in mind that in vitro activities of cytokines on cell lines are detected in artificial systems. Therefore the evaluation of cytokine-activity in malignant lymphomas may provide a better insight into in vivo activities.

Our results demonstrate that high amounts of transcripts of growth factors do indeed occur in some malignant lymphomas.

Five cases of B-cell lymphoma showed strong signals for IL-6 mRNA. Comparison with immunohistochemistry demonstrated low numbers of infiltrating T cells and monocytes in these cases. In situ hybridization in four cases clearly demonstrated a positive IL-6 mRNA signal in 20-60 per cent of the infiltrating cells, two of which had a T-cell content of less than 10 per cent. It can therefore be concluded that the IL-6 signal was produced at least in part by the tumour cells themselves. The same was suggested by Biondi et al. (1989). Only three of our cases had transcripts for IL-4, with high levels in two cases (BCLL-small lymphocytic; cb-diffuse large cell). Two other cases showed weak IL-2 expression, whereas all other cases had no detectable signals.

Comparing the immunohistochemical results with the mRNA expression of IL-2-R (TAC), it is clear that the signals in some cases, especially in those with weak signals, were due to the infiltrating T cells or histiocytes. On the other hand, this comparison also demonstrates that the IL-2 receptor, especially in one case of $\mathrm{HCL}$, was expressed by the tumour cells.

The most striking result of this investigation is the fact that certain cases of well defined malignant B-cell lymphomas expressed high amountsi of B-cell growth factors such as IL-4 or IL-6, whereas other cases of the same entity had no signal for these cytokines. It is thus provocative to speculate on a possible biological activity within those cases with strong signals influencing tumour proliferation and accessory cell activity. 


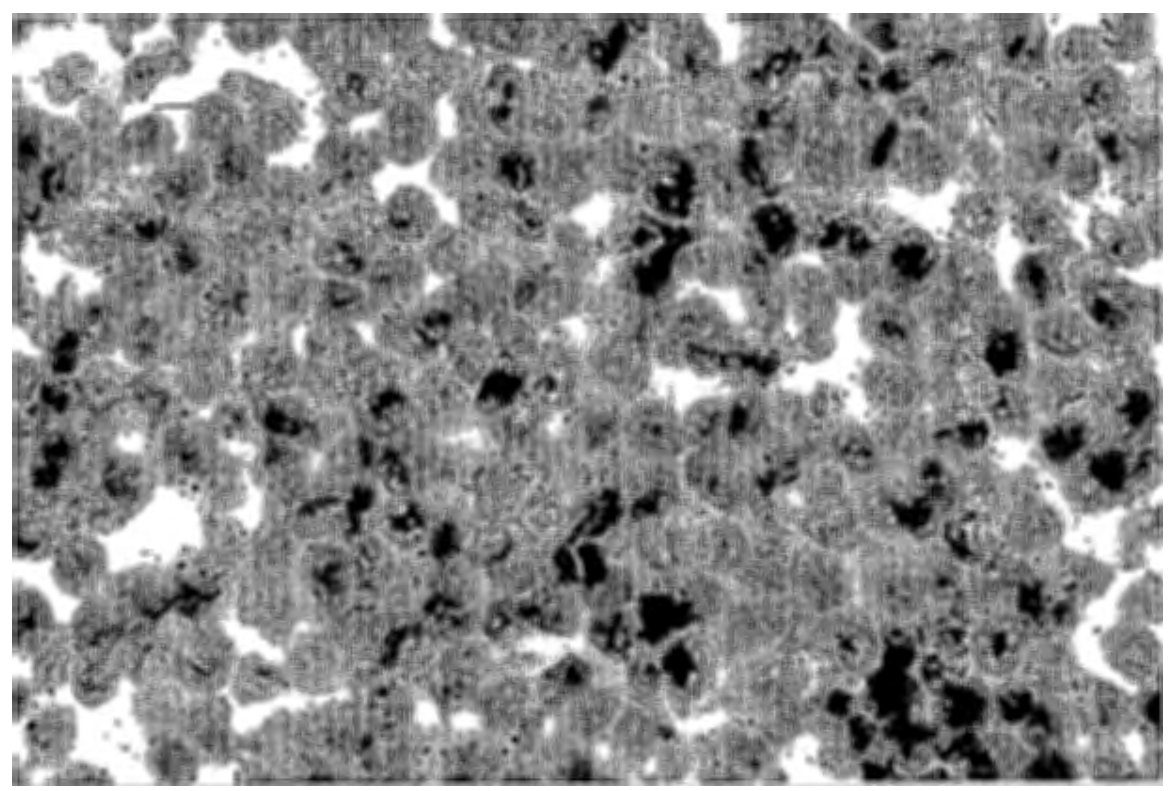

(a)

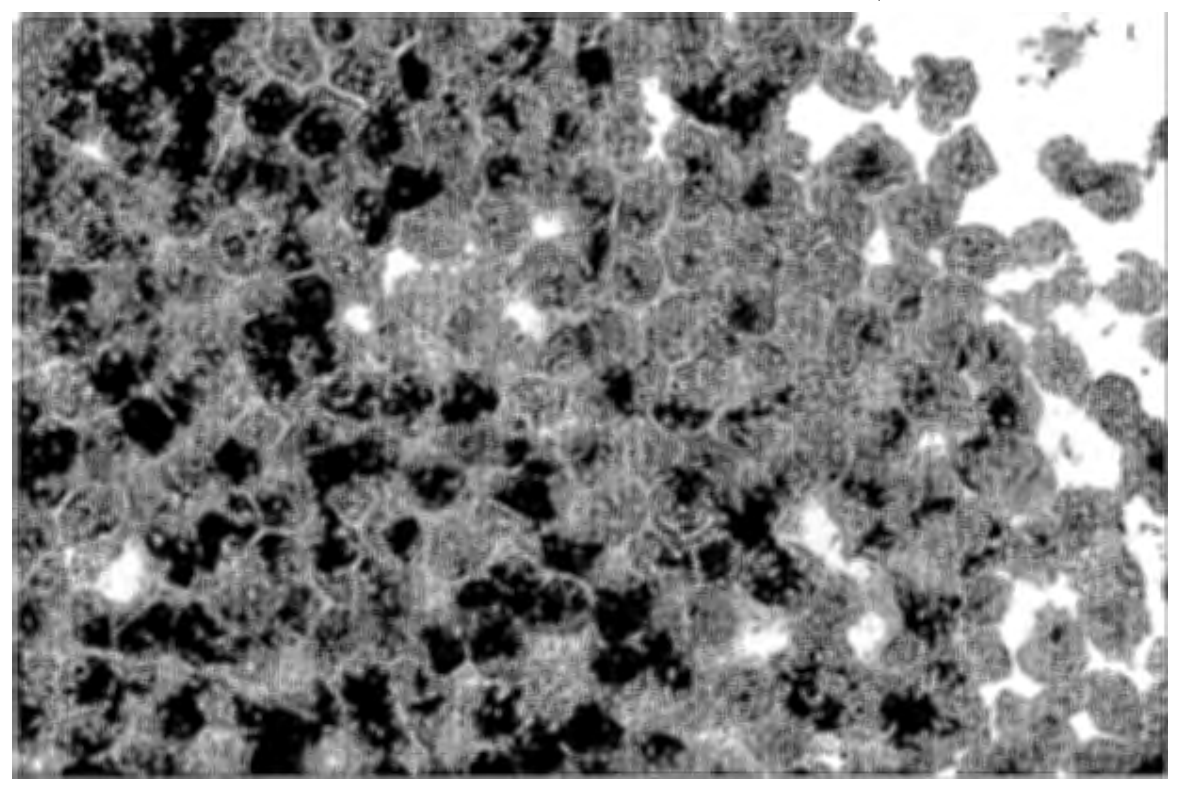

(b)

Figure 2. (a) IL-6 mRNA expression in a high grade B-cell lymphoma (case no. 24-centroblastic) detected by in situ hybridization with antisense IL-6 cRNA. (b) Control section treated with sense IL-6 CRNA in the same case. $5 \mu \mathrm{m}$ cryostate sections, Giemsa stained, $\times 820$. 


\section{REFERENCES}

Abbas, A. K. (1988). A reassessment of the mechanisms of antigen-specific T-cell-dependent B-cell activation. Immunol. Today, 9, 89-94.

Balkwill, F. R., Burke, F. (1989). The cytokine network. Immunol. Today, 10, 299-304.

Biondi, A., Rossi, V., Bassan, R., Barbui, T., Bettoni, S., Sironi, M., Mantovani A., Rambaldi, A. (1989). Constitutive expression of the interleukin-6 gene in chronic lymphocytic leukemia. Blood, 73, 1279-1284.

Chirgwin, J. M., Przybyla, A. E., MacDonald, R. J., Rutter, W. J. (1979). Isolation of biologically active ribonucleic acid from sources enriched in ribonuclease. Biochemistry, 18, 5294-5299.

Freeman, G. J., Freedman, A. S., Rabinowe, S. N., Segil, J. M., Horowitz, J., Rosen, K., Whitman, J. F., Nadler, L. M. (1989). Interleukin 6 gene expression in normal and neoplastic B cells. J. Clin. Invest., 83, 1512-1518.

Glisin, V., Crkvenjakov, R., Byus, C. (1974). Ribonucleic acid isolated by cesium chloride centrifugation. Biochemistry, 13, 2633-2637.

Greaves, M. F. (1986). Differentiation-linked leukemogenesis in lymphocytes. Science, 234, 697-704.

Hirano, T., Yasukawa, K., Harada, H., Taga, T., Watanabe, Y., Matsuda, T., Kashiwamura, S., Nakajima, K., Koyama, K., Iwamatsu, A., Tsunasawa, S., Sakiyama, F., Matsui, H., Taniguchi, T., Kishimoto, T. (1986). Complementary cDNA for a novel human interleukin (BSF-2) that induces B-lymphocytes to produce immunoglobulin. Nature, 324, 73-76.

Kupper, T., Horowith, M., Lee, F., Robb, R., Flood, P. M. (1987). Autocrine growth of T cells independent of interleukin 2: Identification of interleukin 4 (IL4, BSF-1) as an autocrine growth factor for a clonal antigen-specific helper T cell. J. Immunol., 138, 4280-4287.

Lehrach, H., Diamond, D., Wozney, J. M., Boedtker, H. (1977). RNA molecular weight determinations by gel electrophoresis under denaturing conditions, a critical reexamination. Biochemistry, 16, 4743-4751.

Leonard, W. J., Depper, J. M., Crabtree, G. R., Rudikoff, S., Pumphrey, J., Robb, R. J., Krönke, M., Svetlik, P. B., Peffer, N. J., Waldmann, T. A., Greene, W. C. (1984). Molecular cloning and expression of cDNAs for the human interleukin-2 receptor. Nature, 311, 626-631.

Stansfeld, A. G., Diebold, J., Kapanci, Y., Kelényi, G., Lennert, K., Mioduszewska, O., Noel, H., Rilke, F., Sundstrom, C., van Unnik, J. A. M., Wright, D. H. (1988). Updated Kiel classification for lymphomas. Lancet, i, 292-293, 603.

The non-Hodgkin's Lymphoma Pathologic Classification Project (1982). National Cancer Institute sponsored study of classifications of non-Hodgkin's lymphomas. Cancer, 49, 2112-2135.

Taniguchi, T., Matsui, H., Fujita, T., Takaoka, C., Kashima, N., Yoshimoto, R., Hamuro, J. (1983). Structure and expression of a cloned cDNA for human interleukin-2. Nature, 302, 305-310.

Tepper, R. I., Pattengale, P. K., Leder, P. (1989). Murine interleukin-4 displays potent anti-tumor activity in vivo. Cell, 57, 503-512.

Thomas, P. S. (1980). Hybridization of denatured RNA and small DNA fragments transferred to nitrocellulose. Proc. Natl. Acad. Sci. U.S.A., 77, 5201-5205.

Touw, I., Delwel, R., Bolhuis, R., V. Zanen, G., Löwenberg, B. (1985). Common and pre-B acute lymphoblastic leukemia cells express interleukin 2 receptors, and interleukin 2 stimulates in vitro colony formation. Blood, 66, 556-561.

Tweeddale, M., Jamal, N., Nguyen, A., Wang, X. H., Minden, M. D., Messner, H. A. (1989). Production of growth factors by malignant lymphomas cell lines. Blood, 74, 572-578.

Uchiyama, T., Kamio, M., Kodaka, T., Tamori, S., Fukuhara, S., Amakawa, R., Uchino, H., Araki, K. (1988). Leukemic cells from some adult T-cell leukemia patients proliferate in response to interleukin-4. Blood, 72, 1182-1186.

Wörmann, B., Mehta, S. R., Maizel, A. L., LeBien, T. W. (1987). Low molecular weight B cell growth factor induces proliferation of human B cell precursor acute lymphoblastic leukemias. Blood, 70, 132-138.

Yee, C., Biondi, A., Wang, X. H., Iscove, N. N., de Sousa, J., Aarden, L. A., Wong, G. G., Clark, S. C., Messner, H. A., Minden, M. D. (1989). A possible autocrine role for interleukin-6 in two lymphoma cell lines. Blood, 74, 798-804.

Yokota, T., Otsuka, T., Mosmann, T., Banchereau, J., DeFrance, T., Blanchard, D., DeVries, J. E., Lee, F., Arai K-J. (1986). Isolation and characterization of a human interleukin cDNA clone, homologous to mouse B-cell and T-cell stimulating activities. Proc. Natl. Acad. Sci. U.S.A., 83, 5894-5898.

Zinn, K., DiMaio, D., Maniatis, T. (1983). Identification of two distinct regulatory regions adjacent to the human $\beta$-interferon gene. Cell, 34, 865-879. 